\title{
Research on Innovation Model of Cultivation of the Professional Judgment Ability of Accounting Major Students
}

\author{
Jun FENG \\ Wuhan Business University, Wuhan, 430050, China \\ E-mail: fengjun7608@126.com
}

Key Words: Accounting Professional Judgment; Problems; Innovation Model; Applied Practice Teaching

\begin{abstract}
The enterprise accounting policy choice and the processing of accounting events depend on the accounting personnel's professional experience, knowledge level and practical ability. It is a necessary quality for accounting personnel under the new situation. As training base of future accounting talents, Colleges and universities should renew the education idea actively and strengthen the cultivation of professional judgment ability of accounting major students. This paper will explore the training mode, analyze the present situation of cultivation and also make research on how to strengthen the professional judgment ability.
\end{abstract}

\section{Introduction}

With the comprehensive implementation of accounting standards of principle-guided enterprises, more and more space is left for professional judgment of accounting personnel. [1] Guided by basic principles, the accounting professional judgment covers most of the accounting and auditing work. As the market competition is increasingly fierce, social economic composition, organization form and employment mode, interest relationship and social distribution are becoming more and more diversified. [2]Moreover, Emerging technologies such as network, e-commerce and financial instruments have involved into the accounting field and become one fresh topic in this field. In this complex and changeful accounting environment, accounting personnel will face more and more uncertain economic matters and the related accounting standards is gradually contracted leading to an increasing space of accounting professional judgment. [3] How to improve the accounting professional judgment ability has become the common focus on the foreign theoretical and practical fields and the urgent problem to solve. [4] In the process of learning new accounting standards, we can deeply realize that under the original system-based accounting calculation system, the thinking mode that the accounting calculation work is used to completing in accordance with the articles already can not adapt to the reality of accounting reform. As the companies face increasing uncertainties of the economic matters, accurate affirmation and measurement of the value of the assets and liabilities and the current profits and losses and the improvement of the quality of accounting information are practical problems that need accounting personnel to solve. They not only need to learn and master comprehensive professional and related knowledge but also continually develop their ability of independent thinking and accurate judgment. The level of accounting professional judgment ability can influence the quality of the judgment and is directly related to the correct reflection of the enterprise's financial position, business performance and cash flow information and ultimately affects if the information users can make scientific decisions. [5] Therefore, the issues of how to improve the ability of accounting professional judgment have received widespread concern of the theoretical and practical fields and government department. 


\section{Existing Problems and Cause Analysis of Cultivation of Accounting Major Students' Professional Judgment Ability}

\section{A. Existing Problems of Cultivation of Accounting Major Students' Professional Judgment Ability}

a. There are misunderstandings on the cultivation of theoretical knowledge to students.

In the cultivation of applied accounting talents, the improvement of the students' professional skills and accounting professional judgment ability is emphasized and students' mastery of theoretical knowledge of accounting cannot be ignored. However, in the process of cultivation, to increase practice teaching hours, some universities and colleges reduce and contract accounting professional courses, in particular, part strong theoretical specialized courses are excluded causing the division of content of the accounting discipline system thus students lack deep understanding of theoretical knowledge and their professional vision is too narrow affecting students' comprehensive grasp of accounting specialized knowledge. In fact, both the cultivation of applied talents and the improvement of professional judgment ability must be based on the premise of better grasp of accounting theoretical knowledge.

b. It is insufficient for the cultivation of the students' practical skills.

Because a large number of colleges and universities aim to cultivate applied accounting talents, accounting major students' practical skills training is the content of the common attention in the accounting teaching reform. But the students' practical skills training is a complicated system which needs to improve the practice teaching link such as experiment, internship and graduation design and also the security measures such as faculty construction and practice teaching base construction. Many colleges often do not have a mature thought and form supporting reform schemes so the reform is a mere formality and they fail to explore deeply.

\section{B. Cause Analysis of Cultivation of Accounting Major Students' Professional Judgment Ability}

a. The training system of accounting professional judgment ability still needs to be greatly improved.

Due to lack of strong financial supports and policy inclination, although accounting teaching reform currently has been preliminarily established a series of practice teaching links from experiment, production practice, social practice to graduation design, many colleges still have insufficient recognition about the goal and role of teaching links. Main problem is that the reform does not have a unified system of practical ability training and not closely combine the practice with theoretical knowledge.

b. The curriculum settings and teachers' disposition does not meet requirements.

The curriculum settings of accounting major in our colleges and universities are usually based on the talent training objectives and teaching plans in accordance with the characteristics of the subject system and according to the difficulty of the course, it is developed step by step to guide students to gradually understand the professional knowledge. However, this curriculum mode has showed many disadvantages such as old course content, not timely reflection to the new economy transaction, single curriculum structure and no courses in improving accounting professional practical ability. In addition, curriculum evaluation lack test of students' practical ability and operational ability so students cannot adapt to the change of new technology, In the aspect of teachers' disposition, many colleges still tend to teacher's theoretical level and education level without a specialized experimental teacher and do not cultivate teachers' practical ability and carry out the training for teachers' professional quality.

C. The cultivation of professional judgment ability lack logic relationship between each link.

The cultivation of accounting professional judgment ability mainly depends on the improvement of the practice teaching link which includes course experiment, production practice, social practice, graduation design and term thesis in most colleges. But the link arrangement should reflect certain logical order and different weight value instead of simple parallel or random arrangement. For example, experiment courses should follow the setting of theoretical courses and 
production practice and social practice should be arranged before term thesis and graduation design to encourage students to treat practice with the theoretical knowledge to deepen the students' thinking of accounting theory.

\section{The New Pattern of College Accounting Major Students Professional Judgment Ability}

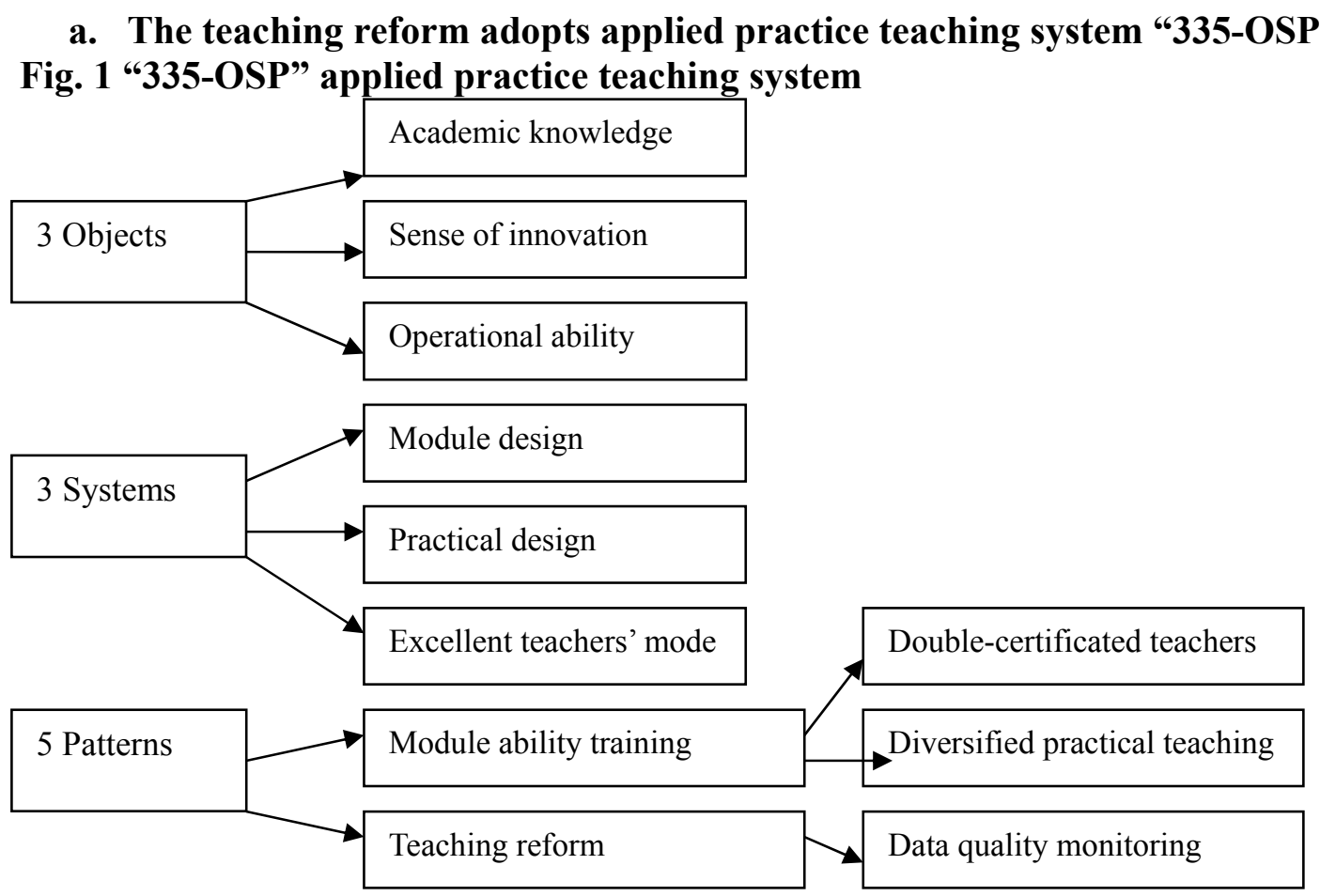

To improve the accounting professional judgment ability, colleges should summarize from three dimensions: training objectives, training system and training content and innovatively build the new pattern of practice teaching system "335-OSP" ( 3 objectives, 3 systems and 5 patterns). The first " 3 " represents the scientific positioning of accounting professional talent training objectives which is cultivation of applied management talent with solid basic knowledge, innovative consciousness and practice ability. The second "3" implies reconstruction of professional teaching system including flexible modular curriculum system Settings and training of operational ability. The third "5" represents innovation of training ways. The colleges can carry on innovation by strengthening the double-type teaching staff construction, setting modular operational ability training system, reforming teaching ways creatively, holding diversified practice teaching activities and monitoring scientific teaching quality.

\section{Put Applied Practice Teaching “335-OSP” Into Practice}

The cultivation of the professional judgment ability needs not only solid professional theoretical knowledge but also abundant practical experience. To cultivate students' professional judgment ability, in the teaching process, it is suggested:

\section{A. Teaching hours should be guaranteed.}

Adjust the current teaching plan; according to the present practice teaching situation of each school, appropriately increase the proportion of practical teaching; increase corresponding accounting skill training in multi-level teaching process of the primary, intermediate and senior accounting lessons and provide practice skill training in the different periods of the same level; guarantee time for students' application ability training.

\section{B. The content should be complete.}

In case analysis practice teaching, try to restore the true nature of transactions and events and keep proper elements without simplification and abridgement; through multi-level and multi-link 
practical accounting teaching, increase the students' perceptual knowledge in accounting; improve the quality of practical teaching to achieve the purpose of strengthening professional judgment ability.

C. The forms should be diversified.

In practical teaching, students can test their level of theoretical knowledge and conduct self assessment on whether they have the professional judgment ability. In the process of implementation, each school can choose practice teaching mode according to the specific situation: classroom practice demonstration, case analysis, individual simulation practice, period simulation practice, graduation synthesis simulation practice and off-campus internship and break the routine that only the junior or senior students can start the internship. Through extensive contacts with society, students' communication and coordination ability, team cooperation ability and lifelong learning ability are further developed and the professional judgment ability is fundamentally improved.

D. The strategic alliance of industry-university-research cooperation should be established and accounting practice teaching should be put into practice.

The strategic alliance of industry-university-research cooperation is the effective way to cultivate applied accounting talents and improve students' professional judgment ability. It is suggested to establish the strategic alliance with the employer as the main body and the market as the guidance, strengthen close cooperation between school and employer, require students to accumulate practical experience and designedly build cultivation mode with college teaching as the main body and practice as the supplement. Meanwhile, enterprises and institutions are expected to perform social responsibility to set up accounting personnel training platform and promote the cultivation of the applied accounting talents.

\section{Conclusions}

In the teaching of accounting major lessons of colleges and universities, the cultivation of accounting talents should improve the professional judgment ability of accounting personnel. Accounting professional judgment is not only a strong professional subjective activity but also an activity through the while accounting process. Therefore, in accounting professional teaching, the teachers should develop the students' ability of professional judgment which will be related to the quality of accounting information and the rational use of capital resources. As the colleges cultivate accounting personnel, they need to locate a reasonable accounting talents training target, improve the professional judgment ability, strengthen the practice link in teaching, cultivate students' accounting professional judgment ability and cultivate more accounting talents for the society.

\section{Acknowledgement}

Comment: Subject Name: Construction and Development Research of Applied General Courses in Colleges and Universities - an Example of Investment and Financing Course. (Project No: 201Y013)

\section{References}

[1] James W. Hesford,Sung-Han (Sam) Lee,Wim A. Van der Stede,S. Mark Young. Management Accounting: A Bibliographic Study[J]. Handbooks of Management Accounting Research . 2007

[2] Jane Baxter, Wai Fong Chua. Alternative management accounting research-whence and whither [J]. Accounting, Organizations and Society. 2002 (2)

[3] Yaozheng TANG. On Rural Financial and Accounting Work under the Background of Rapid Agricultural Economic Development[J]. Asian Agricultural Research. 2013(06)

[4] Handing Control to Locals[J]. Beijing Review. 2012(32)

[5] Comparative Analysis on Two Accounting Systems of Rural Economic Originations [J]. Asian Agricultural Research. 2011(04) 
